\title{
ПРИВЛЕЧЕНИЕ ИНВЕСТИЦИЙ В ИНФРАСТРУКТУРНЫЕ ПРОЕКТЫ В РОССИИ
}

\author{
(C) 2020 Ганеев А. М. \\ Научный сотрудник \\ Институт экономики РАН, Россия, Москва \\ E-mail: Azat.g@rambler.ru \\ SPIN-код: 9372-3330, AuthorID: 703748
}

В данной статье рассматриваются формы и механизмы государственно-частного партнерства как инструмент привлечения инвестиций в инфраструктурные проекты. Автор анализирует опыт развития государственно-частного партнерства в современных условиях.

Ключевые слова: привлечение инвестиций, государственно-частное партнерство, инфраструктуpa.

В России прямые иностранные инвестиции в небанковском секторе в первом квартале 2020 года составили $\$ 0,2$ млрд. по сравнению с $\$ 10,3$ млрд. в первом квартале прошлого года [1].

Привлечение частных инвестиций - важнейшее условие для развития экономики. В текущей ситуации все большее значение для Российской федерации обретает стимулирование роста не только внешних, но и внутренних частных инвестиций в условиях внешнеэкономических ограничений. Привлечение инвестиций в инфраструктурные проекты приобретает особой значение для стабильного и качественного развития экономики России.

В современных условиях государственночастное партнерство становится одним из ключевых инструментов для привлечения внешних и внутренних частных инвестиций. Согласно Зельднеру А. Г., ГЧП - это система институтов и механизмов, учитывающая региональную, муниципальную, отраслевую и ведомственную специфику и направленная на взаимодействие партнерских отношений в виде договора (соглашения, контракта) с взаимными обязательствами, распределительными отношениями, хеджированием рисков, предполагающая совместную деятельность субъектов рыночных отношений [2].

Государственно-частное партнерство ставит целями: поиск и привлечение инвесторов и их ресурсов, развитие и совершенствование производственной и социальной инфраструктуры, предоставление необходимых товаров и услуг населению, активизация инновационной деятельности, развитие экономики регионов и страны в целом.
Одной из наиболее распространенных форм ГЧП является концессия. Посредством конкурса определяется инвестор, обязующийся по контракту провести работы по строительству и(или) ремонту, а также соответствующему оснащению объекта концессионного соглашения, получая при этом временные права на управление и эксплуатацию, а также получение прибыли в процессе пользования объектом.

Например, в 2019 году между Правительством Самарской области и хозяйственным партнерством «Концессионная компания «Обход Тольятти» было подписано концессионное соглашение о строительстве обхода Тольятти с мостовым переходом через Волгу. Стоимость проекта составляет 121 млрд. рублей. Со стороны государства будет вложено 67 млрд. рублей, частный партнер привлечет - 54 млрд. рублей. Срок концессионного соглашения - 20 лет. Частная сторона строит и эксплуатирует данный объект на протяжении срока соглашения, возвращая вложенные средства путем взимания платы за проезд.

На 2020 год, согласно данным Минэкономразвития, в России было реализовано или реализуется около 3,1 тыс. концессионных соглашений. Предполагаемый объем инвестиций по ним более 1,7 трлн. руб. Около 1,2 трлн. руб.внебюджетные инвестиции, 0,5 трлн. руб.- государственные инвестиции [3].

Одной из форм ГЧП также являются контракты жизненного цикла. Контракт жизненного цикла предполагает строительство и эксплуатацию частным партнером объекта контракта. Существенным отличием от концессий является гарантия государства по возврату инвестиций 
на создание и эксплуатацию. Таким образом, существенно снижаются риски частного инвестора. Участки автодорог М-1 «Беларусь» и М-4 «Дон» являются примерами контрактов жизненного цикла.

Соглашение о ГЧП, МЧП является еще одной формой ГЧП. Посредством заключения Соглашения о ГЧП будет реализован проект по строительству лечебно-реабилитационного корпуса СПб ГБУЗ «Городская больница N 40». В 2015 году Соглашение о ГЧП было заключено руководством г. Санкт-Петербург, ООО «Невская медицинская инфраструктура», а также городской больницей N 40.

Частный инвестор построит, оснастит и обязуется осуществлять обслуживание объекта соглашения. Городская больница № 40 предоставляет медицинские услуги. Срок осуществления проекта установлен в 10,5 лет, общий объем инвестиционных обязательств составит - 9,9 млрд. рублей. Частный инвестор вернет свои затраты и получит прибыль путем прямых платежей со стороны города и арендных платежей со стороны больницы № 40.

Соглашения о ГЧП и МЧП на данный момент немногочисленны. На 2020 год подписано 25 соглашений о ГЧП, МЧП, с общим объемом инвестиционных обязательств 59,6 млрд. рублей (внебюджетные инвестиции - 45,5 млрд. рублей) [4].

В 2005 году в России были созданы особые экономические зоны - форма ГЧП. Закон дает определение особой экономической зоны как части территории Российской Федерации, которая определяется Правительством Российской Федерации и на которой действует особый режим осуществления предпринимательской деятельности, а также может применяться таможенная процедура свободной таможенной зоны». ОЭЗ создается сроком на 49 лет.

Согласно сведениям Минэкономразвития РФ, на 2020 действует 33 особые экономические зоны. С 2005 г. по настоящее время в ОЭЗ было привлечено свыше 760 резидентов. Объем заявленных инвестиций - около 1 трлн. рублей, объем фактически внесенных инвестиций - свыше 420 млрд. рублей, число созданных рабочих мест - порядка 38 тысяч [5].

Однако, по результатам проверок контролирующих органов, оказалось, что значительная часть привлеченных средств была инвестирована в четырех особых экономических зонах -
Алабуга, Липецк, Санкт-Петербург и Технополис (Москва). В связи с чем были закрыты некоторые зоны с низкими показателями эффективности.

В 2014 года был подписан закон о создании территорий опережающего социально-экономического развития (ТОР). Закон определяет территории опережающего социально-экономического развития как часть территории субъекта Российской Федерации, включая закрытое административно-территориальное образование, на которой, в соответствии с решением Правительства Российской Федерации, установлен особый правовой режим осуществления предпринимательской и иной деятельности в целях формирования благоприятных условий для привлечения инвестиций, обеспечения ускоренного социально-экономического развития и создания комфортных условий для обеспечения жизнедеятельности населения. Срок создания ТОР 70 лет.

Согласно данным Минэкономразвития на 2020 год создано 111 территорий опережающего социально-экономического развития. Было привлечено 639 резидентов, свыше 27 тыс. рабочих мест было создано, объем инвестиций составил порядка 69 млрд. рублей, а прибыль резидентов составила свыше 149 млрд. рублей [6].

В апреле 2020 года была создана новая перспективная форма ГЧП - соглашения о защите и поощрении капиталовложений (СЗПК). Данная форма соглашения предлагает инвестору возможность зафиксировать текущие условия землепользования и налогов. Срок применения фиксации зависит от объема инвестиций: не более шести лет - проекты с инвестициями до 5 миллиардов рублей, 15 лет - проекты с инвестициями от 5 до 10 миллиардов, 20 лет - проекты с инвестициями от 10 миллиардов. При превышении объема инвестиций свыше 10 миллиардов рублей могут быть зафиксированы неналоговые платежи (на период до трех лет), таможенные пошлины на вывоз. Также государство может предоставить субсидию на осуществление проекта.

Минимальный объем инвестиций установлен в 250 миллионов рублей, в сферах сельского хозяйства, цифровой экономики, экологии - 500 миллионов, обрабатывающего производства 1,5 миллиарда рублей, в других сферах -5 миллиардов рублей.

Формы и механизмы ГЧП, на наш взгляд, получают все более широкое применение в Рос- 
сийской Федерации, однако необходимо дальнейшее развитие и распространение в связи с успешным опытом их использования в России и в мире. Однако существует несколько основных причин, мешающих расширению использования форм и механизмов государственночастного партнерства:

- отсутствие опыта и низкая квалификация чиновников, занимающихся проектами ГЧП вне крупных городов;

- сложности с поиском баланса рисков разных сторон при реализации проектов. Необходимо справедливое распределение рисков между государством и бизнесом;

- отсутствие со стороны государства гибкости и быстрой реакции на изменения;

- законодательная база должна развиваться в соответствии с современной ситуацией.

Государственно-частное партнерство по- зволяет государству реализовывать проекты, необходимые для развития экономики страны, создающие новые рабочие места, при этом экономя бюджетные средства и сохраняя функции контроля за собой. Частный инвестор получает возможность получить прибыль на длительный срок с низким уровнем риска. Население получает необходимые качественные услуги и товары. Государственно-частное партнерство взаимовыгодно для всех сторон.

Государственно-частное партнерство, на наш взгляд, является одним из наиболее перспективных инструментов привлечения инвестиций, в том числе в инфраструктурные проекты. Формы и механизмы государственно-частного партнерства поддерживают и дают возможность интенсивного развития экономики регионов и России в целом с основной целью - повышение качества жизни россиян.

\section{Библиографический список}

1. https://www.rbc.ru/economics/13/04/2020/5e9451489a79479e5a66d28e

2. Государственно-частное партнерство в условиях инновационного развития экономики [Монография] / Под ред. А. Г. Зельднера, И.И. Смотрицкой. М.: ИЭ РАН, 2012. С.13

3. https://www.rbc.ru/economics/25/02/2020/5e4fcdf89a7947decf57ae33

4. https://www.economy.gov.ru/material/file/6b5f12f3140cf044f1f715d18dfdef0a/gchp\%2021.02.2020.pdf.pdf

5. https://www.economy.gov.ru/material/directions/regionalnoe_razvitie/instrumenty_razvitiya_territoriy/osobye_ ekonomicheskie zony/

6. https://www.economy.gov.ru/material/directions/regionalnoe_razvitie/instrumenty_razvitiya_territoriy/tor/

7. Концессии как драйвер управления процессом привлечения частных инвестиций в инфраструктурные проекты / Зельднер А. Г., Осипов В. С.Проблемы теории и практики управления. 2019. № 8. С. 65-73.

8. Концессии как механизм улучшения инвестиционного климата в стране / Халтурин Р.А.Экономика и предпринимательство. 2015. № 5-1 (58). С. 108-111. 